\title{
АНАЛІЗ АНГЛО-УКРАЇНСЬКОГО ПЕРЕКЛАДУ АУДІОВІЗУАЛЬНОЇ ПРОДУКЦІЇ НА ОСНОВІ ФІЛЬМУ ВЕСА АНДЕРСОНА «ГОТЕЛЬ «ГРАНД БУДАПЕШТ»
}

\begin{abstract}
Анотація. Стрімкий розвиток мультимедійних засобів, їх поширення та доступність призвів до їх постійного використання у повсякденному житті, що своєю чергою зумовило поширення аудіовізуальної продукції. У статті означено аудіовізуальну продукцію як полісеміотичну, тобто як таку, що подае інформацію не лише через текст, але й за допомогою зображень та музики. Зроблено короткий огляд технік перекладу, які застосовуються до продукції такого штибу та окреслено переваги та недоліки субтитрування та дубляжу. У цій статті зроблено спробу порівняти оригінальний англійський сценарій кінофільму «Готель «Гранд Будапешт» з українськими субтитрами та виявити причини неточностей перекладу за допомогою розробленого чіткого шаблону для розрізнення та систематизації відхилень від оригінального тексту.
\end{abstract}

Ключові слова: аудіовізуальна продукція, дубляж, субтитрування, полісеміотичність, перекладацькі техніки.

Shyika Yuliia, Krekhovetska Kateryna Lviv Polytechnic National University

\section{ANALYSIS OF THE ENGLISH-UKRAINIAN TRANSLATION OF AUDIOVISUAL PRODUCTS BASED ON WES ANDERSON'S FILM "THE GRAND BUDAPEST HOTEL"}

Summary. The rapid development of multimedia, its availability and accessibility have resulted in the constant use of these technologies in everyday life. This phenomenon caused a wide spread of audiovisual products. In the article, the scientific researches on audiovisual products and the challenges of translation have been reviewed. Audiovisual products have been defined as polysemiotic, i.e as products that present information not only through text but also through images and music. To make a full and professional translation, all information that is received through different channels should be synchronized and has to comply with the rules and restrictions. Such restrictions have caused arguments that subtitles cannot be referred to as a proper translation, but an adaptation of the original text. A brief review of translation techniques applied to audiovisual products has been made and the advantages and disadvantages of subtitling and dubbing have been outlined. It has been noted that poor translation can make a negative impact on the audience and can create a negative impression about an audiovisual product. Despite some disadvantages, dubbing and subtitling are the most common and accepted methods of audiovisual translation. Different types of subtitles have been described. In this article, a comparison of the original English script of the film "The Grand Budapest Hotel" and Ukrainian subtitles has been made. The reasons for translation inaccuracies have been identified; deviations from the original text have been distinguished and systematized. Four main factors that influenced the accuracy and quality of Ukrainian subtitles in the film "The Grand Budapest Hotel" have been identified.

Keywords: audiovisual products, dubbing, subtitles, polisemiotic, translation technics.

Постановка проблеми. Сучасні мультимедійні технології сприяють швидкому та широкому поширенню аудіовізуальної продукції як національної, так й іноземної. Це явище викликало гостру потребу у якісному перекладі такої продукщії. Аудіовізуальний переклад - це переклад полісеміотичних текстів, представлених на екрані для масової аудиторії [7]. Мультимедійні продукти, такі як фрільми, документальні фільми, серіали тощо, перекладаються іншими мовами, задля охоплення ширшої аудиторії та збільшення їх популярності та споживання. Аудіовізуальні матеріали можна перекласти за допомогою субтитрів або дубляжу. Незалежно від того, який метод застосований, переклад вихідного тексту повинен здійснюватися шляхом впровадження ряду різноманітних прийомів перекладу.

Аналіз останніх досліджень і публікацій. Питання перекладу аудіовізуальної продукщії, його особливостей та проблем стало об'ектом дослідження як вітчизняних, так і зарубіжних науковщі. Серед них можна виокремити наукові праці Н. Абабілової, Г. Денисової, Н. Матківської, Г. Андерсона, М. Де Марко, Г.Л. Де Роса, M. Коріуса та інших.
Виділення не вирішених раніше частин загальної проблеми. Актуальність дослідження зумовлена тим, що вперше було проведено аналіз англо-українського перекладу аудіовізуальної продукції на основі кінофільму фільму «Готель «Гранд Будапешт».

Мета статті. Головною метою статті є шляхом контрастивного аналізу порівняти оригінальний англійський сценарій кінофільму «Готель «ранд Будапешт» 3 українськими субтитрами та виявити причини неточностей перекладу за допомогою розробленого чіткого шаблону для розрізнення та систематизації відхилень від оригінального тексту.

Виклад основного матеріалу. Для перекладу аудіовізуальної продукції використовуеться широкий термінологічний спектр: екранний переклад, переклад фольмів, мультимедійний переклад. Завдяки своїй інклюзивності, термін аудіовізуальний переклад найбільш широко використовуеться як в індустрії, так і в перекладацьких дослідженнях.

Професор та лінгвіст Хорхе Діаз-Сінта із Університетського коледжу в Лондоні та Пілар Ореро, перекладознавиця в Автономному університеті Барселони, у своїх роботах розрізняють два 
основні підходи до перекладу аудіовізуальної продукщії [5]: переозвучування та субтитрування. У першому випадку вхідні звукові дані передаються на слух цільовою мовою шляхом вставки нового звукового супроводу. При субтитруванні відбувається перехід від розмовного до письмового дискурсу, а діалог та інші мовленневі елементи передаються на екран в письмовому вигляді. В рамках цих двох комплексних підходів можна встановити подальші класифікащії методів або моделей аудіовізуального перекладу.

В субтитруванні прийнято розрізняти міжмовні та внутрішньомовні моделі. Внутрішньомовні моделі включають в себе субтитри мовою оригіналу, що дозволяе використовувати їх як і для вивчення іноземних мов, так і для кращого сприйняття аудіовізуальної продукції людям вадами слуху. Під час субтитрування телепередач, що транслюються в прямому ефрipi, субтитри для людей із вадами слуху можна створити за допомогою голосового набору тексту - техніки, за допомогою якої спеціалізоване програмне забезпечення для розпізнавання мови перетворює оригінальний діалог у субтитри [6]. Окрім цього, серед класифрікованих моделей субтитрів розрізняють театральне субтитрування - проекцію субтитрів над сценою для оперних чи драматичних вистав, а також франсаб - франатські аматорські субтитри, які створюють шанувальниками певного жанру і зазвичай є у вільному доступі в Інтернеті [5].

Аудіовізуальна продукція - полісеміотична, тобто інформація передається не лише через текст, а й за допомогою зображень, жестів, інтонації, музики тощо. Щоб отримати повнощінний переклад, всі матеріали, що надходять через різні канали, повинні синхронізуватися, відповідати нормам та обмеженням. Крім того, текст має просторові обмеження, це обумовлено розмірами екрану: підзаголовок повинен містити максимум два рядки, від 32 до 41 символів у рядку, інакше глядачі не зможуть прочитати через обмеження в часі. Для того, щоб відповідати таким обмеженням, репліки персонажів скорочуються приблизно на $25 \%$. При цьому текст позбавляють так званого «шуму», тобто інфрормащії, яка може призвести до непорозуміння або зменшити ефективність тексту [2]. Внаслідок цих обмежень, деякі перекладознавці стверджують, що субтитри є адаптацією вихідного тексту, а не перекладом [9].

Вирізняють дві найбільш широковживані міжмовні моделі переозвучування - дублювання та закадровий голос. Перекладач Ф. Шом вважає дубляж типом аудіовізуального перекладу, який складаеться із заміни оригінальної доріжки діалогів у фрільмі (або будь-якому іншому виді аудіовізуальної продукції) іншою доріжкою, на якій перекладені діалоги записані мовою перекладу [3]. Дубляж часто асоціюеться із фонограмою, і саме це порівняння підкреслює необхідність синхронізації перекладеного діалогу з артикуляцією дійових осіб на екрані. Однак не у всіх випадках дубляжу потрібна артикуляційна синхронізація, наприклад, коли персонаж (чи оповідач) знаходиться за межами кадру. На відміну від дубляжу, при переозвучуванні звукова доріжка не замінюеться, а перекривається: оригінал та перекладені доріжки діалогу одночасно подаються цільовому глядачеві. При цьому гуч- ність оригінальної доріжки суттєво зменшена, хоча все ще чутна.

Загалом слід зазначити, що одне із завдань дубляжу полягає в синхронізації губ, оскільки саме це робить кінцевий продукт правдоподібним для цільової аудиторії. Тому завдання перекладачів полягає не лише у перекладі, але й у пристосуванні діалогів до жестів та рухів губ акторів. Зазвичай особливу увагу звертають на губні приголосні, голосні низького та високого підняття, щоб запобігти комунікативному шуму та фонотичній синхронії [2]. Наслідком ціеї адаптації $є$ продумані псевдоспонтанні фррази; письмовий текст, який намагаеться наслідувати спонтанність усного дискурсу. Цей текст повинен виконуватися акторами дубляжу, роль яких полягає у наданні тексту найвищого ступеню достовірності, модулюючи інтонацію та імітуючи тон акторів в оригіналі [2].

Стрімкий розвиток технічних засобів доступних сучасним перекладачам зумовлений вкоріненням цифрових технологій не тільки в науці, а й у повсякденному житті та поширенням аудіовізуальної продукції. Варто зауважити, що найбільш очевидні зміни виявляються у збільшенні кількості та подовженні рядків, скороченні часу експозиції субтитрів і зростання швидкості читання, що, безумовно, суттево вплинуло на спосіб здійснення фрактичної передачі мовлення.

Різноманітні мультимедійні елементи можуть відігравати ключову роль, коли мова йде про глибше вивчення культури різних країн та їх звичаїв. Візуальні деталі на екрані автоматично передають культурні норми: оточення, вбрання та зовнішність персонажів, жести та міміка. При перекладі різноманітних засобів масової інфрормащї, аудиторія, що взаємодіє із результатом кінцевого перекладу, може сприймати вміст у звуковій чи письмовій формі рідною мовою, і одночасно реагувати на ті ж візуальні елементи, наявні в оригінальній версії, як і носії мови-джерела перекладу. Крім того, іноземна аудиторія може брати участь у глобальному дискурсі, який часто створюється тоді, коли певні аудіовізуальні продукти стають особливо успішними та рекламуються у засобах масової інформації.

Якщо йдеться про труднощі тлумачення культурних феноменів, зазвичай виникає потреба локалізації перекладу із врахуванням культурних особливостей. Постає питання як перекласти терміни, притаманні певній країні чи нації. При перекладі унікальних понять 3 мови оригіналу, які не мають відповідників у мові перекладу, перед спеціалістами постає завдання знайти спосіб досягнення подібного значення при перекладі. Переклади висловів та гра слів часто спричиняють труднощі, оскільки вони не тільки пов'язані 3 культурою чи безпосередньо зі сценою на екрані, але часто містять історичний чи соціальний контекст. Якщо дубльована або субтитрована версія аудіовізуальної продукції міститиме таку фрразу без мовної та культурної адаптації до мови перекладу, то виникне ймовірність того, що певні сцени або неправильно трактуватимуться цільовою аудиторією, або загалом унеможливлять розуміння матеріалу [6].

Окрім того, варто зазначити чому за певних умов в аудіовізуальному перекладі застосовують- 
ся різні техніки перекладу. Субтитрування та дубляж пропонують різне розуміння мови фрільму. Переваги та недоліки дубляжу та субтитрування при аудіовізуальному перекладі досліджуються багатьма науковцями, серед яких Г. Готліб, Л. Перез-Гонзалез, Ж.Л. Де Роса, С. Лавіоса та інші. Ф. Карамітроглу підсумовуе розвідки науковців у галузі перекладу аудіовізуальної продукції та окреслює такі переваги та недоліки субтитрування та дубляжу [8]:

- Субтитрування $є$ більш дидактичним способом аудіовізуального перекладу, ніж дубляж, оскільки аудиторія безпосередньо взаємодіє із іноземною культурою та мовою. Загалом, у країнах, де переважно використовуеться субтитрування, рівень володіння іноземними мовами вищий.

- Дубляж надає більшої достовірності кінщевому продукту, оскільки його можна зрозуміти безпосередньо, а деякі культурні явища адаптують або замінюють, щоб зробити їх більш зрозумілими для цільової аудиторії.

- До недоліків дубляжу можна віднести унеможливлення оцінити акторську гру та голоси героїв в оригіналі, оскільки дубляж пропонує більш штучний та повністю позбавлений спонтанності кінцевий продукт.

- Слабкою стороною субтитрів є їх негативний вплив на візуальну складову аудіовізуального продукту. Вони заважають глядачу зосередитися на зображенні, а натомість спрямовують його увагу на текст. Окрім цього, при застосуванні техніки субтитрування, немає змоги відтворити такі лінгвістичні варіації, як акцент, інтонація чи будь-які інші просодичні елементи мовлення. Варто також зазначити, що дубляж здатний наслідувати мовні варіації, але результат може суттево відрізнятися від оригіналу, що спричиняе втрату автентичності.

- Дубляж є більш правдоподібним для глядачів, але набагато дорожчий, ніж субтитри, а процес дублювання - ресурсо- та часозатратним. Виробники короткометражної продукції надають перевагу субтитруванню.

- Субтитри передбачають семіотичну зміну (перехід з усного на писемне мовлення), і саме тому неминуче спотворюють оригінальне повідомлення, коригуючи його відповідно до часових та просторових обмежень. В окремих випадках субтитрування повністю позбавляе оригінал супроводу.

- При дублюванні перекладений матеріал замінюють для досягнення синхронізації, тому результат може неповністю відповідати оригіналу.

Як і субтитри, так і дубляж - це сфери, в яких для досягнення високої якості перекладу потрібно володіти професійним рівнем навичок. Неякісний переклад спричинить негативний вплив на аудиторію та може повністю зіпсувати враження про аудіовізуальний продукт. Незважаючи на вищезазначені недоліки, дублювання та субтитрування є найбільш розповсюдженими та прийнятими методами аудіовізуального перекладу, оскільки їх переваги вагоміші.

Завдяки комплексному підходу було виокремлено чотири головні чинники, що вплинули на точність та якість українських субтитрів до кінофільму «Готель «І ранд Будапешт»:
1. Ідіоматичні конструкціі.

2. Вульгаризми.

3. Локалізація перекладу.

4. Перекладацька некомпетентність.

Ідіоми часто стають серйозними перепонами в перекладі, особливо для недосвідчених перекладачів. Оригінал сценарію написаний вкрай красномовно та містить велику кількість яскравих стилістичних засобів і словесних конструкцій, які не мають аналогів в українській мові. В англійському тексті можемо знайти дрразу: "То ту surprise, he was distinctly taken aback." Українською вона була перекладена як: "На мій подив, він явно не чекав такого питання." Безсумнівно, головний посил автора можна зрозуміти в українській версії, та вдаючись до більш літературного перекладу, ідіому was taken aback можна було б тлумачити як «він був приголомшений».

Іншим прикладом недосконалого ідіоматичного перекладу є репліка одного із героїв: "had left me, as the expression goes, "Gespannt wie ein Flitzebogen," that is, on the edge of my seat". $\mathrm{Y}$ вітчизняному перекладі "on the edge of my seat" буквально передано як "в напруженолу очікуванні розв'язки”. Набагато вдалішим та влучнішим $є$ український фрразеологічний еквівалент "як на голках".

Розглянемо оригінальний вислів “In the small hours of the evening of 19 October”. Сталий вислів "in the small hours" використовуеться для позначення відрізку часу після півночі до світанку. Існуе український фрразеологізм “глупа ніч”, що описуе аналогічний часовий проміжок, але в перекладі "in the small hours" зустрічаємо як "Пізно ввечері".

Звертаючись до неточностей перекладу спричинених вульгаризмами, варто зауважити, що фільм «Готель «Іранд Будапешт» вийшов на вітчизняні екрани із віковим обмеженням 14+. Це обумовлене значною кількістю ненормативної лексики та кримінальними арготизмами, що трапляються в оригіналі. 3 огляду на це, нелітературна мова оригінальних персонажів була частково замінена допустимими українськими відповідниками.

Під час тлумачення фррази «Call the goddamn plumber!» перекладники вдалися до перекладацької граматичної трансформації, а саме опущення. Тому в українській версії тотожним висловом є «Подзвони нарешті сантехніку!». Граматична трансформація опущення була використана і під час перекладу репліки You can't arrest him simply because he's a bloody immigrant. - Ви не можете арештувати його лише за те, що він елігрант.

«What's wrong with you, you goddamn snitch?» ця фрраза використовувалась в діалозі головного героя Мосье Іустава X із співкамерниками у в'язнищі. - Український переклад фррази «Та що 3 тобою таке, інфрорматоре паскудний?». «Інформаторе» не відображає стилістичного забарвлення, закладеного в "goddamn snitch». Задля збереження стилістичної цілісності діалогу в перекладі, було б доцільно застосувати арготизм «стукач» чи «базікало».

В спробах адаптувати переклад до культурних звичаїв цільової аудиторії, мовознавці вдаються до найрізноманітніших перекладацьких технік 
та задіюють різноманітні види трансорормацій. Яскравим підтвердженням цього є переклад репліки «Rabbit, salad? Mmm. Pouilly-Jouvet '52, plus a split of the brut. - Кролик, салат? Пуйї-Жюве 52 року, плюс чвертку брюту.» Оригінальне "a split of" не прив'язане до жодної конкретної одиниці виміру об'єму, а тому може інтерпретуватись по-різному: «крапля», «дещиця», тощо.

В англійському сценарії зустрічається фрраза "Which way to the safe house?» Серед українських відповідників safe house - укриття, схованка, притулок. Та саме криївка $є$ найбільш стилістично влучним еквівалентом. Український переклад в субтитрах: “Де наша криївка?»

Часто перекладачам доводиться відступати від оригіналу не лише задля локалізації кінцевого продукту. Різні системи вимірювання закордоном та в Україні можуть завадити аудиторії повноцінно засвоїти матеріал із першоджерела. Тому "They only had the half-ounce.» трансформувалась в українську «У них було пише 15 мілілітрів.». Для зручності глядачів англійські унщії перерахували в розрахунку на більш звичні нам міліграми.

Щоб розглянути хиби спричинені непродесійністю перекладача варто звернутись до наступного уривку із сценарію: "A number of years ago, while suffering from a mild case of "Scribe's Fever," a form of neurasthenia common among the intelligentsia of that time.." - «Багато років тому, потерпаючи від легкого нападу лихоланки Скрайба, виду неврастенії, поширеного в колах інтелігенції тих часів». "Scribe» - це архаїчний іменник, який використовувався для позначення особи, яка копіює документи, особливо в часи до винайдення друкарства. В поданому контексті
«Scribe» використовується для сатири невдалих спроб пера тогочасної інтелігенції. Тому більш точним перекладом $е$ “лихоманка писаки".

Вдаючись до дослівного перекладу, лінгвіст ризикуе натрапити на підводні камені під час тлумачення окремих рядків. Наприклад «Each month, his emissary, known as Deputy Kovacs, arrived to review the books and convey messages on behalf of the mysterious proprietor.» Запропонований нам український відповідник «депутат Ковакс» є наслідком саме дослівного перекладу. З огляду на контекст, «заступник Ковакс» є оптимальним варіантом зміненого формулювання.

Висновки і пропозиції. Переклад аудіовізуальних продуктів є одним з ключових елементів міжнародної та міжкультурної комунікації. Окрім того, численні дослідження доводять позитивний вплив використання аудіовізуальних продуктів на оволодіння іноземними мовами. Переклад аудіовізуальної продукції - це складне завдання, що вимагає певного підходу та професійних навичок. Навіть прості бесіди, які не несуть смислового навантаження, повинні відтворюватись цільовою мовою чітко і точно, 3 дотриманням засад культури та етикету цільової аудиторії. Позаяк існуе обмеження у просторі та часі, то субтитри повинні відповідати чітким критеріям задля комфорту глядачів та адекватного сприйняття кінопродукту. Разом тим слід звернути увагу на те, що субтитри також повинні синхронізуватися зі звуком та зображенням, що відображаються на екрані. Що стосуеться дубляжу, то текстам, які використовуються при перекладі аудіовізуальної продукції, слід мати однакову довжину з оригіналом.

\section{Список літератури:}

1. Bogucki L. Perspectives on Audiovisual Translation / L. Bogucki // Peter Lang, 2010. - 206 p.

2. Bravo, J.M. A New Spectrum of Translation Studies / J.M. Bravo // Universidad De Valladolid, 2004. - Pp. $215-216$.

3. Chaume, F. Translating nonverbal communication in dubbing / F. Chaume // Amsterdam/Philadelphia: John Benjamins, 1997. - Pp. 315-326.

4. Cintas J.D. Audiovisual Translation: Subtitling / J.D. Cintas, A. Remael // New York: Routledge, 2014. - P. 9.

5. Cintas J.D. Voiceover and dubbing / J.D. Cintas, P. Orero // Amsterdam: John Benjamins, 2010. - 445 p.

6. Eco U. Mouse or Rat? Translation as Negotiation / U. Eco // London: Weidenfeld \& Nicolson, 2003. - P. 110.

7. Gottlieb H. Multidimensional Translation: Semantics turned Semiotics / H. Gottlieb // Copenhagen: MuTra, 2005. - P. 13

8. Karamitroglou F. Towards a Methodology for the Investigation of Norms in Audiovisual Translation: the Choice between Subtitling and Revoicing in Greece / F. Karamitroglou // Rodopi, 2000. - 300 p.

9. Pinto S.R. Audiovisual Translation: Theoretical and methodological challenges / S.R. Pinto // John Benjamins Publishing Company, 2018. - 146 p.

10. Sanderson J.D. Focusing on Audiovisual Translation Research / J.D. Sanderson, C. Botella-Tejera // Universitat de València, 2019. - $240 \mathrm{p}$.

\section{References:}

1. Bogucki L. (2010) Perspectives on Audiovisual Translation. Peter Lang, 206 p.

2. Bravo J.M. (2004) A New Spectrum of Translation Studies. Michigan: Universidad De Valladolid, pp. 215-216.

3. Chaume F. (1997) Translating nonverbal communication in dubbing. Amsterdam/Philadelphia: John Benjamins, pp. $315-326$.

4. Cintas J.D., Remael A. (2014) Audiovisual Translation: Subtitling. New York: Routledge, 284 p.

5. Cintas J.D., Orero P. (2010) Voiceover and dubbing. Amsterdam: John Benjamins, 445 p.

6. Eco U. (2003) Mouse or Rat? Translation as Negotiation. London: Weidenfeld \& Nicolson, pp. 110-111.

7. Gottlieb H. (2005) Multidimensional Translation: Semantics turned Semiotics. Copenhagen: MuTra, pp. 13-15.

8. Karamitroglou F. (2000) Towards a Methodology for the Investigation of Norms in Audiovisual Translation: the Choice between Subtitling and Revoicing in Greece. Rodopi, 300 p.

9. Pinto S.R. (2018) Audiovisual Translation: Theoretical and methodological challenges. John Benjamins Publishing Company, $146 \mathrm{p}$.

10. Sanderson J.D., Botella-Tejera C. (2019) Focusing on Audiovisual Translation Research. Universitat de València, $240 \mathrm{p}$. 